F. Reprod. Fert. (1974) 41, 447-451

\title{
UPTAKE OF TRITIATED THYMIDINE BY PRIMORDIAL GERMINAL CELLS IN THE OVARIES OF THE ADULT SLENDER LORIS
}

\author{
G. F. X. DAVID, T. G. ANAND KUMAR AND T. G. BAKER*† \\ Department of Anatomy, All India Institute of Medical Sciences, New Delhi-110016, \\ India, and ${ }^{*}$ Hormone Laboratory, Department of Obstetrics and Gynaecology, \\ University of Edinburgh, Edinburgh EH3 9ER
}

(Received 15th May 1974)

\begin{abstract}
Summary. Six adult lorises (Loris tardigradus lydekkerianus) in anoestrus were selected for study. Four of the animals were pretreated with an injection of $0.5 \mathrm{mg}$ oestradiol- $17 \beta$, two were given FSH $(2 \times 50$ i.u. with a 12-hr interval), while the remaining two were not treated with hormones. All of the animals were subsequently given a subcutaneous injection of $0.5 \mathrm{mCi}\left[{ }^{3} \mathrm{H}\right]$ thymidine and their ovaries were recovered for autoradiography $24 \mathrm{hr}$ later.

It was found that the non-follicular germinal cells within 'nests' in the ovarian cortex actively incorporated the radioisotope. Some of the labelled germinal cells appeared to reach the pachytene-diplotene stages of meiotic prophase, although this would not be expected to occur in such a short time after treatment. None of the labelled germinal cells appeared to enter upon the phase of follicular growth, although a few (especially in ovaries treated with oestrogen and FSH) seemed to be in primordial follicles consisting of an incomplete layer of flattened cells.
\end{abstract}

\section{INTRODUGTION}

The occurrence in the ovaries of adult prosimian primates of non-follicular germinal cells in various stages of mitosis (oogonia) or meiotic prophase (oocytes) indicates that oogenesis in these animals continues throughout life (for review, see Anand Kumar, 1974). This pattern of oogenesis is in marked contrast to that found in the majority of mammalian species in which the prediplotene stages of germinal cell maturation are completed during late fetal or early postnatal life (see Brambell, 1956; Franchi, Mandl \& Zuckerman, 1962; Baker, 1972). Autoradiographic studies of the ovaries of Galago (Ioannou, 1967; Butler \& Juma, 1970; T. C. Anand Kumar and T. G. Baker, unpublished observations), Nycticebus and Loris (T. G. Anand Kumar and T. G. Baker, unpublished results), following injection of $\left[{ }^{3} \mathrm{H}\right]$ thymidine, have shown that cells resembling oogonia and oocytes persist throughout adult life and incorporate precursors of DNA. Quantitative differences in the size of the population of

\footnotetext{
† Correspondence and reprint requests: Dr T. G. Baker, Hormone Laboratory, Department of Obstetrics, Simpson Memorial Maternity Pavilion, Royal Infirmary, Edinburgh EH3 9ER.
} 
non-follicular germ cells (related to the stages of the oestrous cycle, or occurring as a result of the administration of exogenous steroid hormones during anoestrus in the loris) have indicated that the multiplication of such cells is under endocrine control (Anand Kumar, 1968a, b). However, the question remains to be resolved as to whether these newly formed germinal cells can acquire a follicular envelope and contribute to the population of definitive germinal cells (follicular oocytes at the diplotene stage of meiotic prophase).

The present studies were carried out to determine the fate of the non-follicular oocytes in anoestrous lorises, and also in animals treated with exogenous steroid and gonadotrophic hormones.

\section{MATERIALS AND METHODS}

\section{Animals}

Six healthy adult slender lorises (Loris tardigradus lydekkerianus) at the anoestrous stage of the reproductive cycle were used according to the following schedule: (1) two animals were injected subcutaneously with $\left[{ }^{3} \mathrm{H}\right]$ thymidine (sp. act. $9000 \mathrm{mCi} / \mathrm{mmol}$, at a dose of $0.5 \mathrm{mCi} /$ animal) and their ovaries were recovered $24 \mathrm{hr}$ later; (2) four lorises were pretreated with a subcutaneous injection of oestradiol-17 $\beta(0.5 \mathrm{mg}$ in $0.5 \mathrm{ml}$ propanediol/animal), followed 12 hr later by an injection of $\left[{ }^{3} \mathrm{H}\right]$ thymidine (as above). Ovaries from two of these lorises were recovered $24 \mathrm{hr}$ after the thymidine treatment, while the remaining two animals were given 100 i.u. FSH (NIH-FSH-S3) as two subcutaneous injections of 50 i.u. $12 \mathrm{hr}$ apart. These ovaries were recovered $24 \mathrm{hr}$ after the last injection of FSH.

\section{Autoradiography}

The ovaries were fixed in Bouin's fluid, embedded in paraffin wax, serially sectioned at $10 \mu \mathrm{m}$ and processed for autoradiography using the dipping technique (with Ilford G5 emulsion) of Rogers (1967). The autoradiographs were developed in Kodak Microdol-X developer 2 weeks after exposure to the $\beta$-radiation from the tritium. The preparations were fixed in sodium thiosulphite, washed in water, and stained through the emulsion with Harris's haematoxylin.

\section{EXPLANATION OF PLATE 1}

Frg. 1. A group of labelled non-follicular germinal cells in various stages of oogenesis in the ovary of an anoestrous loris. $\mathrm{A}=$ atretic germinal cell; $\mathrm{D}=$ oocyte at diplotene; $\mathbf{P}=$ mitotic prophase. $\times 800$.

Fig. 2. Labelled oocyte at diplotene (D) at an early stage of follicular growth in the ovary of an anoestrous loris pretreated with oestrogen. $\times 800$.

Fig. 3. Labelled oocyte at diplotene in the ovary of an anoestrous loris pretreated with oestrogen. Note the single layer of follicle cells (arrowed) around the oocyte. $\times 800$.

Fig. 4. Labelled oocyte at diplotene in a primordial follicle in the ovary of an anoestrous loris pretreated with oestrogen and FSH. The follicular cells are arrowed. $\times 800$.

Fig. 5. Follicle containing an atretic oocyte in the ovary of an anoestrous loris pretreated with oestrogen and FSH. $\times 800$. 

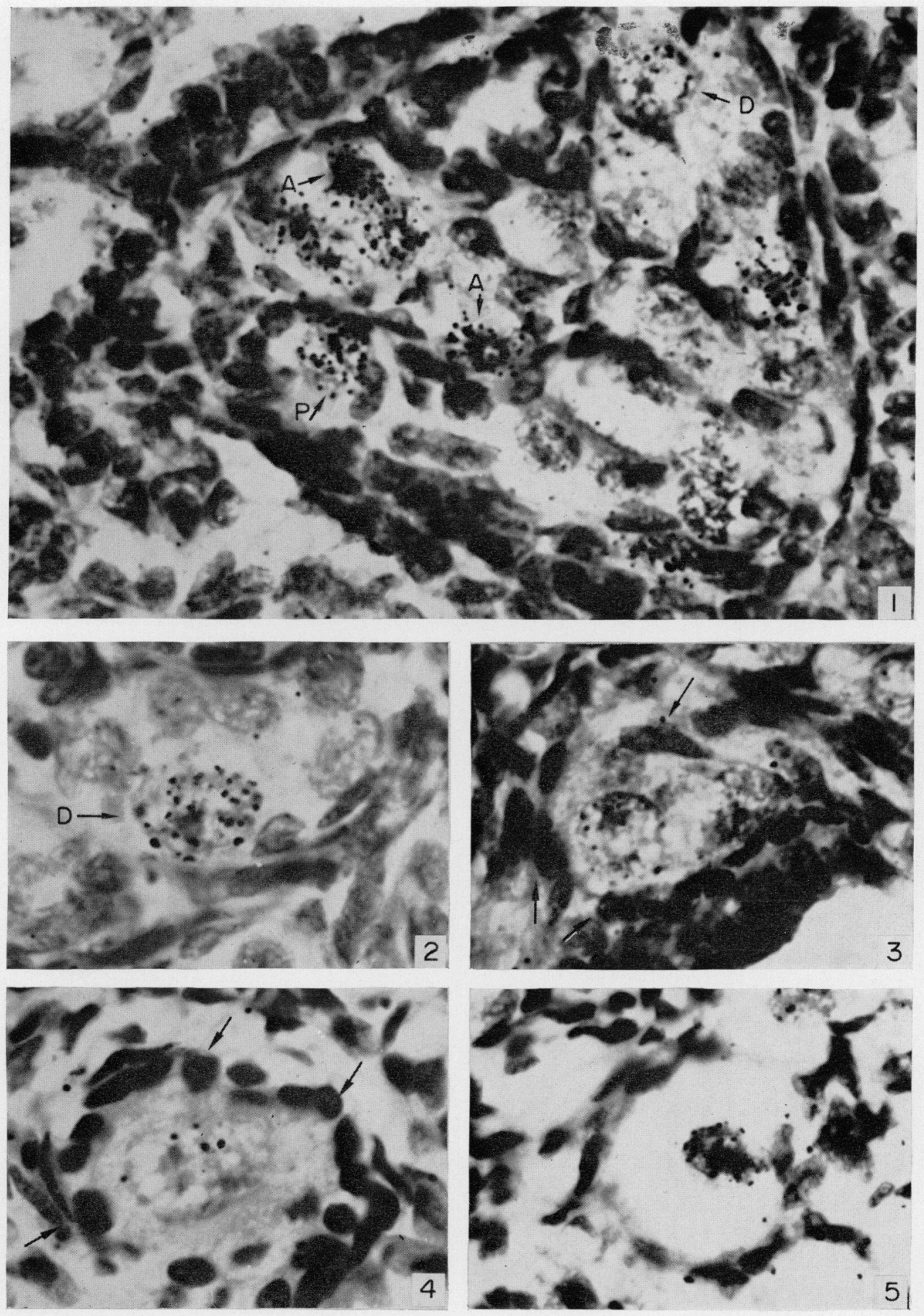


\section{RESULTS}

Examination of the autoradiographs showed that most, although not all, of the non-follicular germinal cells (which were crowded into 'nests') were labelled. They were in various stages of mitosis or undergoing meiotic prophase. Some of the labelled germinal cells appeared to be undergoing degeneration in that their nuclear chromatin was clumped and the cytoplasm appeared 'empty' (Pl. 1, Fig. 1).

The 'nests' of germinal cells in the ovaries of anoestrous lorises contained only labelled oogonia and the early stages of meiotic prophase (Pl. 1, Fig. 1), but the ovaries of lorises which had been pretreated with oestrogen contained oocytes which appeared to be at the pachytene or diplotene stages (Pl. 1, Figs 2, 3 and 4). Some of these were enclosed within primordial follicles consisting of a few flattened granulosa cells (Pl. 1, Fig. 3). Labelled germinal cells enclosed within a complete layer of follicle cells were only encountered in lorises treated with both oestrogen and FSH (Pl. 1, Fig. 4), and larger follicles (with more than one layer of granulosa cells) were not found in any of the treatment groups. There were, however, some labelled germinal cells in small follicles which had undergone atresia (Pl. 1, Fig. 5).

The nuclei of oogonia invariably contained a greater concentration of silver grains/unit area than those of oocytes. The labelling index appeared to decrease with the progressively advanced stages of meiotic prophase and follicular development but it still remained consistently higher than 'background' (Pl. 1, Figs 2, 3 and 4).

\section{DISGUSSION}

The results of the present study have confirmed earlier observations that the non-follicular germinal cells within 'nests' in the ovarian cortex actively incorporate $\left[{ }^{3} \mathrm{H}\right]$ thymidine (see Anand Kumar, 1974). The occurrence of labelled germinal cells in the ovaries of untreated lorises indicates that oogonial divisions and DNA synthesis can occur in the sexually quiescent period, as well as at oestrus and after hormone treatment (see also Anand Kumar, 1968b).

The appearance in the autoradiographs of labelled oocytes at pachytene and/or diplotene was not anticipated since tritiated thymidine is normally incorporated only into oogonia at the ' $S$ ' phase of interphase and into oocytes at the preleptotene stage of meiosis. 'Unscheduled' DNA synthesis can, however, occur after damage to chromosomes at diplotene (see Kofman-Alfaro \& Chandley, 1971; Chandley \& Kofman-Alfaro, 1971). It has been shown for most mammals that the minimum time for the progression of oocytes from preleptotene to diplotene is 5 days, and it is often considerably longer (see Baker, 1972). By contrast, this interval for the adult loris would have to be no more than $24 \mathrm{hr}$ since this was the maximum time of exposure to the $\left[{ }^{3} \mathrm{H}\right]$ thymidine. Alternatively, it would be necessary to postulate that late replication of some chromosomes occurs, probably at pachytene. The 'unscheduled' nature of this DNA synthesis has not yet been determined.

In the anoestrous loris, labelled non-follicular germinal cells do not enter 
upon a phase of follicular growth. However, animals in a similar stage of the cycle which were treated with oestrogen did possess labelled oocytes surrounded by one or more flattened granulosa cells: the organization of such follicles was even more pronounced after treatment of the animals with both oestrogen and FSH, and it might be inferred that the non-follicular germinal cells contribute to the population of definitive oocytes during each oestrous cycle. Furthermore, it has been shown (Anand Kumar, 1968a, b) that the number of the germinal cells in the 'nests' within ovaries at oestrus is seventeen times higher than during anoestrus and there is a 13-fold increase when anoestrous lorises are treated with oestradiol-17 $\beta$. Once again, these results seem to be unique to the adult prosimian primate and a comparable situation cannot be found at any stage of oogenesis in the majority of other mammalian species which have been studied. Thus, in human and mouse ovaries maintained in organ culture, the progression of oogonia through mitosis and meiotic prophase occurs in the absence of gonadotrophic hormones (Baker \& Neal, 1973, 1974), and the addition of exogenous gonadotrophic or steroid hormones does not modify or accelerate the process (S. Challoner, unpublished observations).

The results of the present study thus reveal a number of fundamental differences between the development of oogonia and oocytes in the ovaries of adult lorises compared to those in other fetal mammals, and further studies should be made of these critical stages in gametogenesis in fetal and adult prosimian primates.

The question of whether any of the non-follicular germinal cells pass through follicular growth to the point of ovulation remains unanswered and the results of the present study certainly provide no evidence for such a view. This would be very difficult to test in the light of technical difficulties in maintaining and breeding this relatively exotic species. On the other hand, the 'nests' of germinal cells may be merely an embryological curio and their seemingly bizarre behaviour (as compared to equivalent germinal cell stages in other species) may be irrelevant to the production of the definitive population of follicular oocytes. Nevertheless, it would be interesting to speculate that the contribution of these germinal cells is related to the formation of follicular and/or interstitial cells that are essential for hormone production rather than to increase the gametogenic capacity of the ovary.

\section{ACKNOWLEDGMENTS}

While this work was carried out, one of us (G.F.X.D.) was a recipient of a fellowship from the Department of Atomic Energy, Government of India. The FSH was generously provided by the Endocrine Study Section, National Institutes of Health, Bethesda, U.S.A. This research was largely supported by the Indian Council of Medical Research and the Ford Foundation. Some of the expenses incurred in the study were defrayed from a grant to T.G.B. by the Population Council, New York. The authors are grateful to Mr S. G. Sharma for his technical assistance. 


\section{REFERENGES}

Anand Kumar, T. G. (1968a) Oogenesis in lorises; Loris tardigradus lydekkerianus and Nycticebus coucang. Proc R. Soc. B, 169, 167.

ANand Kumar, T. G. (1968b) The effects of gonadal hormones on primordial germ cell populations in the slender loris. F. Reprod. Fert. 16, 322.

Anand Kumar, T. G. (1974) Oogenesis in adult prosimians. In Contribution to Primatology. Vol. 3, Reproductive Biology of Primates. Ed. W. P. Luckett. Karger, Basel.

Baker, T. G. (1972) Oogenesis and ovarian development. In Reproductive Biology, 398-437. Eds. H. Balin and S. R. Glasser. Excerpta Medica, Amsterdam.

BAKER, T. G. \& NeAL, P. (1973) Initiation and control of meiosis and follicular growth in ovaries of the mouse. Annls Biol, anim. Biochem. Biophys. 13, 137.

Baker, T. G. \& NeAL, P. (1974) Oogenesis in human fetal ovaries maintained in organ culture. 7. Anat. (in press.)

Brambell, F. W. R. (1956) Ovarian changes. In Marshall's Physiology of Reproduction, 3rd edn, Vol. 1, Part 1, pp. 397-542. Ed. A. S. Parkes. Longmans Green, London.

Butler, H. \& Juma, M. B. (1970) Oogenesis in adult prosimians. Nature, Lond. 226, 552.

Chandley, A. C. \& Kofman-Alfaro, S. (1971) Unscheduled DNA synthesis in human germ cells following UV irradiation. Expl Cell Res. 69, 45.

Franchi, L. L., MANDL, A. M. \& ZuCKerman, S. (1962) The development of the ovary and the process of oogenesis. In The Ovary, Vol. 1, pp. 1-88. Ed. S. Zuckerman. Academic Press, New York.

Ioannou, J. M. (1967) Oogenesis in adult prosimians. F. Embryol. exp. Morph. 17, 139.

Kofman-Alparo, S. \& Ghandey, A. P. (1971) Radiation induced DNA synthesis in spermatogenic cells of the mouse. Expl Cell Res. 69, 33.

Rogers, A. W. (1967) Techniques of Autoradiography. Elsevier, Amsterdam. 